INFORMASI - ISSN (p) 0126-0650; ISSN (e) 2502-3837

Vol. 49, No. 1 (2019), pp.1-10.. doi: http://doi.org/10.21831/informasi.v49i1.25432

\title{
COMMUNICATION PATTERN BETWEEN FEMALE BREADWINNERS AND THEIR CHILDREN
}

\author{
Chatia Hastasari \\ chatia@uny.ac.id \\ Communication Science Study Program \\ Faculty of Social Sciences \\ Universitas Negeri Yogyakarta
}

\begin{abstract}
This study examines the communication pattern between female breadwinners and their children and the barriers in that communication process. This qualitative study was carried out among 12 female breadwinners from low-income families in Wedomartani Village, Ngemplak, Sleman, Special Region of Yogyakarta. It is drawn from the study that, first, there is good interpersonal communication between a female breadwinner and her children. It is clearly seen as all factors leading to an effective interpersonal communication are fulfilled, namely a) openness - the mother is actively creating a pleasant conversation so that her children will feel more comfortable in telling her everything that happens to them; b) empathy - the mother instills a sense of independence and respect for others in her children; and c) positive behaviors - the mother has a strong commitment to improve her family's condition as shown in all her positive behaviors. Second, as the mother and her children can interchangeably be the communicator (sender) or the communicant (recipient) of information, this communication is categorized as direct (face-to-face), either one-way or two-way. Third, the barrier existing in the communication process between a female breadwinner and her children is mainly related to the mother's limited time available to do her main duties as a mother, causing her housework to become abandoned. Another obstacle in this communication process is due to the children's psychological condition that is affected by the lack or even the absence of father's roles in their family, leading to an unstable emotion.
\end{abstract}

Penelitian ini bertujuan untuk mengetahui bagaimana pola komunikasi wanita sebagai kepala keluarga dengan anaknya dan apa saja hambatan yang terjadi pada proses komunikasi antara wanita kepala keluarga dengan sang anak. Penelitian ini menggunakan pendekatan kualitatif dengan sumber data utama para wanita kepala keluarga miskin di desa Wedomartani, Ngemplak, Sleman yang berjumlah 12 informan. Hasil penelitian ini adalah 1) komunikasi interpersonal yang terjalin antara ibu sebagai wanita kepala keluarga dengan sang anak sudah berjalan dengan baik. Hal itu Nampak 
dari pemenuhan faktor-faktor yang dapat memengaruhi komunikasi interpersonal agar menjadi lebih efektif diantaranya a) Keterbukaan yang ditandai dengan adanya peran aktif sang ibu dalam proses komunikasi agar sang anak merasa nyaman bercerita segala hal; b) Empati yang ditanamkan oleh sang ibu pada diri sang anak adalah kemandirian dan rasa menghargai orang lain terutama orang tua; dan c) Perilaku positif yang ditunjukkan dari komitmen yang kuat sang ibu dalam memperbaiki kondisi keluarga. 2) pola komunikasi interpersonal yang terjadi bersifat langsung (tatap muka) baik satu arah maupun dua arah. Hal ini tampak dari posisi komunikator (pengirim pesan) dan komunikan (penerima pesan) dapat dilakukan oleh ibu maupun anak. Dan 3) hambatan dalam proses komunikasi yang terjalin antara ibu sebagai wanita kepala keluarga dengan anaknya saat berinteraksi adalah minimnya waktu yang dimiliki oleh sang ibu menyebabkan tugas dan kewajiban utamanya sebagai seorang ibu di rumah menjadi terbengkalai dan hambatan lainnya adalah kondisi psikologis anak yang mengalami kekurangan atau bahkan kehilangan sosok ayah dalam keluarga menyebabkan emosinya menjadi tidak stabil.

Keywords: Interpersonal Communication Pattern, Communication Barrier, Female Breadwinner

\section{INTRODUCTION}

Nowadays, it is very common, in either developed or developing countries, that a woman plays a role as the breadwinner of her family (Wooden, M., \& Hahn, M., 2014; Latshaw, B. A., \& Hale, S. I., 2016). In developed countries, most financially independent and highly educated women can support their family on their own. In contrast, those with this breadwinning responsibility in developing countries are women with low education and economic status who predominantly work in informal sectors. This condition causes a miserisasi i.e. a woman suffers from and has to bear the burden of poverty (Ernawati, 2013: 97).

Linda Amalia Sari Gumelar, the Minister for Women Empowerment and Child Protection (WE-CP) of Indonesia in 2009 - 2014, asserted that in 2011 Indonesia had approximately seven million female breadwinners. This number made up more than $14 \%$ of the total number of households in Indonesia (www.babylonish.com, 2017). Moreover, a survey on the CommunityBased Welfare Monitoring System (CBWMS) conducted by the National Secretariat of Female Breadwinner Empowerment (FBE) in 111 villages across 17 provinces under the working areas of FBE, reveals that in every four families, there was one family headed by a woman. These women had to take over the men's responsibilities for varied reasons: their husband died, their marriage ended in divorce, they were abandoned and left, they were not or not yet married, their husbands decided to become polygamists, their husbands worked in distant places, their husbands had permanent illnesses, and their husbands were unemployed (www.pekka. or.id, 2017). These facts clearly show that the number of female breadwinners in Indonesia is quite big.

Wedomartani, Ngemplak, Sleman is one of the villages in Indonesia that has a community for female breadwinners, namely Wijaya Kusuma Training Center. These women come from many different family backgrounds. Some are divorced at a young age, some others are abandoned by their husbands for a second wife, and the rest are widowed due to their husbands' death. During an interview in the preliminary study, the chief of Wijaya Kusuma Training Center informed that regarding the jobs, these female breadwinners worked as laundry workers, bakers, and tailors. The low wages or salaries they earn every day, week, or month certainly cannot meet all their family needs. It also means that they cannot rely solely family's earned income from their 
husband (Clark, A., 20oo; Drago, R., Black, D., \& Wooden, M., 2005). This condition is worsening as they spend more time working than communicating with their children (an interview with Mrs. Hastuti, 2017).

Sumardiningsih et al. (2001: 2) affirm that a shift in woman's roles can be a crucial probleminafamilywithafemalebreadwinner. This shift happens when a woman has to play roles not only as a mother, but also as a father when socializing with their children. Unquestionably, this is a great burden for a female breadwinner to act as both a mother and a father in this communication process.

Communication is a substantial element in a family problem solving process to achieve harmony (Noh, Yusooff, \& Hasim, 2013). Harmony in a family can be achieved through a quality communication. A quality communication between parents and their children can happen only if both parties have a good relationship, meaning that they understand, trust, and love each other, whereas poor quality communication indicates thelack ofattention, understanding, trust, and affection between the two parties (Hopson and Hopson, 2002: 96). In addition, Bigner (2002) asserts that family relationship is a complex interaction between parents and children and is as a factor affecting the decision-making process in the family (Noh et al., 2013).

However, it cannot be denied that some factors may affect the quality of communication in families with a female breadwinner, including (1) mother's low education level - when a mother is not highly educated, it will be difficult for her to catch up with the education development of her children, and it is even worse when many mothers with low economy level cannot afford to give education to their children; and (2) limited time availability - a working mother has less time available to interact with her children due to her work demands, causing her not to know her children's needs.

The lack of quality communication between a female breadwinner playing roles as both a mother and a father and her children may raise some negative impacts on the children's development. Komara (2012) in Syarifatisnaini (2014) finds that the lack of attention from (single) parent will certainly affect the child's mental development. Feeling that they do not get enough attention from their parents, these children will seek attention from other people or even some will feel insecure and depressed. Furthermore, the fact that these female breadwinners are poor brings about another impact on the children's development. Baker (2015) attests that poverty creates a gap in the acceptance status of children with two parents and those with only one parent. According to Benjamin R.M., et al. (2016), these children may lack nutrition and do not have access to quality education (Orfield, 2013), books, and other school supplies (Woessmann, 2015). Without doubt, this is very influential on the mental development of the children who live with only one parent. Thus, it is very important to pay more attention to the communication pattern of a poor family with a female breadwinner in order to maintain harmony with the children and avoid the negative impacts arising from the lack of quality communication on children development.

This phenomenon shows that taking over the roles of a husband in earning a living for the family does not necessarily solve problems in the family with a female breadwinner. Playing roles as both a mother and a father in daily interaction with children is a matter of great attention. Based on the elaborations above, this study focuses on the pattern as well as the barriers in the communication process between female breadwinners and their children.

\section{LITERATURE REVIEW}

\section{Family Communication}

The first and foremost environment for a child is a family. A family is the most basic kinship unit in society. Talibo and Rondonuwu (2017) assert that family as the smallest unit in the society plays a strategic role in shaping one's personality. That is why a child can develop all personalities related 
to social norms existing in a society such as tolerance, etiquette, and moral starting from their family.

Communication in a family is usually face-to-face or interpersonal, where each participant can choose any functions, either as the communicator or as the communicant. According to Mulyana in Aw (2011: 3), interpersonal communication is a face-toface interaction between two or more people, where both the communicator and the communicant can directly send and receive a message, as well as give feedback to the message. In a similarvein, Muhammad (2005: 153) defines interpersonal communication as an information exchange process between a person and at least one other person or usually between two people, where responses can be directly received. By drawing on these two definitions, it can be concluded that interpersonal communication involves two or more people and the message sent by the communicator is directly responded or given feedback by the communicant.

Interpersonal communication is very important in a family in that through effective internal communication, each family member can understand each other's wishes and expectations (Rejeki, 2017). Widjaja (2000) mentions three factors that can make interpersonal communication more effective, namely:

1. Openness

Openness shows two aspects of interpersonal communication. First, by being open to the people interacting with us, we can then make them understand our opinions and thoughts, and consequently our communication will be more effective. Second, openness refers to our willingness to respond to what are said by others honestly and frankly, and vice versa.

2. Empathy

Empathy is the ability of a person to put himself in others' shoes. Showing empathy to others' experiences is possibly the most difficult part in making communication effective, for in doing so, a person does not assess the behavior of others but instead must be able to know their feelings, preferences, values, attitudes, and behaviors.

3. Sportsmanship

Interpersonal communication will be effective if every participant has sportsmanship in him/her, meaning that in an attempt to solve a problem, he/she must not be defensive.

From the above explanation, it can be concluded that in order for interpersonal communication to be effective, some factors must be fulfilled by both the communicator and the communicant. In this study, openness is more about a female breadwinner's openness to her children regarding the family financial condition, or the children's openness to her mother regarding the problems they have in their school or social environments. Empathy is more emphasized on the mother's willingness to listen to all the problems faced by her children and to pay attention to the changes in her children's attitudes and behaviors as they begin to grow up. At last, sportsmanship is related to the spirit or encouragement given by the mother to her children or an apology for not being able to fulfill her responsibilities as a mother who can accompany them at all times.

\section{Family Communication Patterns}

A pattern isa form orstructure. Taliboand Rondonuwu (2017) define a communication pattern as a form or pattern of two or more people's relationship in the process of sending and receiving a message in such an appropriate manner that the intended message can be understood. To measure the quality of family communication, McLeod and Chaffee developed Family Communication Pattern Measurement (FCP) in 1972. They divide family communication pattern into two dimensions, namely concept-orientation and socio-orientation. Concept-orientation emphasizes how family members conceptualize their ideas and the extent to which they are actively involved in a discussion, while socio-orientation appears 
in the efforts of family members to keep and maintain their family unity as well as harmonious relationship with their parents (Bakar \& Aftanorhan, 2016).

Sudjana (2000) highlights three communication patterns that can be used to develop a dynamic interaction in efforts to raise awareness. They are as follows.

1. In communication as an action or one-way communication, the communicator plays an active role as the giver of action and the communicant is as the recipient of the action. An example of this type is speech, which is one-way communication.

2. In communication as an interaction or two-way communication, both the communicator and the communicant can have the same roles as the giver and the recipient of the action.

3. Incommunicationasatransactionormultiway communication, communication involves dynamic interaction not only between the communicator and the communicant, but can also between all other communicant elements.

In this study, the mother and the children, can act as both the communicator and communicant in the communication process.

\section{Female Breadwinners}

In general, the head of a family is a man, as it is related to his function as a breadwinner. Meanwhile, taking care of the children is a wife or mother's responsibility. The roles of a family head tend to be heavier than those of the other family members (Sumardiningsih et al., 2001: 2). The family context in this study is a family that is led by a wife or a mother for varied reasons: loss of husband, divorce, separation, decision not to marry (yet), polygamy, long distance relationship, husband's permanent illness, and husband's unemployment (www.pekka.or.id, 2017). Mosses (2007: 55) in Ernawati (2013) defines a female breadwinner as a woman who has the sole responsibilities for supporting her family. This notion is in line with the definition of a family head, i.e. the one who has both economic and social responsibilities to his/her family. It is also supported by Meisenbach's research findings (2010), she stated that there are six essential elements of FBWs' experiences: having control, valuing independence, feeling pressure and worry, valuing partners' contributions, feeling guilt and resentment, and valuing career progress.

Based on the explanation above, there has been a shift in a woman's status into the breadwinner of the family, and this shift will affect the family communication pattern between her and her children. When there is only one figure for the children to have, there will be something missing in the family, and in this case, the mother will be the only figure in that family life.

Being a female breadwinner is not easy, as she has to fulfill two sides of her responsibilities. On the one hand, she is a mother to her children who has to take care of her children, fulfill her family's nutritional needs, and do the household chores, but, on the other hand, she is a breadwinner who must financially support her family. As a matter of fact, this condition is getting worse as the wage for women is lower than that for men, despite the same job they do (Ernawati, 2013).

\section{Communication Barriers}

Communication can be ineffective due to what is called as 'noise'. In nonverbal communication, noise can appear in mistyping, which will cause the intended messages to be misinterpreted. Meanwhile, in verbal communication, noise can be caused by fast intonation, low volume, and the use of difficult words. In fact, sometimes noise comes not only from the communicator, but also from the communicant. Suprapto (2009: 14) in Nurdianti (2014) asserts that there are three psychological factors causing such noises to happen: 1) selective attention - people tend to expose themselves only to things (communication) that they like; 2) selective perception - when someone is in the middle of communication process, he/she tends to interpret the subject matters based 
on his/her own background knowledge, for it is strongly related to a stereotypical way of thinking; and 3) selective retention even though a person understands what is being communicated, he/she will have the tendency to remember only what he/she wants to remember. From this theory, it can be said that noise in a communication process can be caused by either the communicator or the communicant.

Further, Fajar (2009: 62) mentions five barriers that may hinder communication. First, barriers may be from the communicator (sender). An illustration for this barrier is when a mother coming home from work and feeling very tired, she says something to her children in such a low voice that her children cannot hear it well. Second, barriers can happen in the coding/symbolizing process. This barrier happens because of some factors, like ambiguity in the language being used, differences in the symbols used by the participants, and language complexity. For example, when a child tells his mother the reasons why he has a fight with his younger brother while crying loudly, her mother certainly has to listen to him carefully. The third barrier is that from the use of media in communication. A problem may arise when a mother, for example, with low education level, does not know how to operate a smartphone with its many modern and sophisticated features. Fourth, language barrier may hinder the communicant's interpretation. When a mother tries to teach her children the value of resoluteness, the children can think of her mother as being angry. The last barrier is from the communicant (recipient) side. When a child does not pay attention to what her mother says, for instance, their communication can be ineffective. These five barriers are most likely to be encountered by a female breadwinner when communicating with her children.

\section{METHODS}

This study was qualitative in nature. In a qualitative study, the researchers attempt to analyze and interpret data to find patterns (Creswell \& Miller, 200o). Further, Denzin and Lincoln (2009) point out that a qualitative study involves a variety of empirical materials, such as personal experiences, introspection, life stories, artifacts, cultures, histories, and values that reflect the routine activities in one's life. The main problems to be investigated in this study have to be described explicitly to facilitate the exploration process of the occurring phenomena:

1. What is the communication pattern between female breadwinners and their children like?

2. What are the barriers in the communication process between female breadwinners and their children?

This study was carried out in Wedomartani Village, Ngemplak, Sleman in September 2017. The primary data sources in this study were 12 female breadwinners from poor families: three from the divorce group, six from the widow group, and the other three from the abandoned group. Meanwhile, the research objects were the communication pattern between a female breadwinner and her children as well as the barriers they have in their communication process.

To answer the research problems, the researcher collected the data through an indepth, open, and participative interview. To validate the data, the researcher carried out a source triangulation by comparing and checking the trustworthiness of information from different sources through an interview. The triangulation results showed whether the data were consistent, inconsistent, or contradictory. In this way, the researchers could give a better description in varied perspectives regarding the phenomena under study (Pawito, 2007: 99).

\section{RESULT AND DISCUSSION}

\section{Communication Patterns between Female Breadwinners and their Children}

Many reasons can explain why a family is led by a woman: death of her husband, divorce, separation, polygamy, long distance relationship, husband's permanent illness, and unemployed husband (www.pekka.or.id, 2017). 
These conditions are also experienced by women in Wedomartani Village, Ngemplak, Sleman, Yogyakarta. Sincefamilyiseverything to them, they are willing to be a single parent and try to maintain their family's harmony. One prerequisite condition to reach that harmony is quality communication.

Communication is a very important element for any families from any backgrounds, particularly for families with female breadwinners. The communication in this family will form a structure called communication pattern, that is face-toface or interpersonal. This pattern makes it possible for every participant to choose whether he/she will be the communicator or the communicant (Effendi, 1993). The followings are the factors affecting the interpersonal communication between female breadwinners and their children.

1. Openness

In this study, openness in the communication process between a female breadwinner and her children can exist by the active roles of the mother. Openness is very crucial especially in a one-way communication, like when giving understanding of the fact that their father had passed away and now their mother has to take over the roles as a breadwinner for the family. It must be done to avoid any possible detrimental effects on the children's psychological well-being. This is in line with what Komara (2012) in Syarifatisnaini (2014) asserts that the lack of attention from (single) parents will certainly affect their children's mental development. Feeling this lack of attention, these children will seek attention from others or some will feel insecure and depressed.

2. Empathy

The female breadwinners in this study try to instill empathy in their children by teaching them the value of being independent. They want their children to be strong individuals and to have respect for others, especially for their parents. However, in instilling empathy, having a strong commitment is necessary, particularly for families where the wife earns higher salary than the husband does, or even where the husband is unemployed.

3. Positive Behavior

Like in instilling empathy, a strong commitment from both the husband and the wife is required in inculcating positive behaviors in their children. This commitment is related to the roles and duties of a woman as both a wife and a mother for her children. For a working mother, she will not have enough time and energy for her family. That is why this commitment is undeniable to prevent any possible misunderstandings.

The fulfillment of those aforementioned factors shows that communication is not only about a series of stimuli and responses, but it is also a process of sending and receiving messages that are already perceived by a female breadwinner and her children. Moreover, the communication process in this case plays an essential role in changing a child's personality through the interaction and support in that process.

A dynamic interaction between mothers and their children in this study is in two communication patterns: a one-way and a two-way face-to-face interpersonal communications.

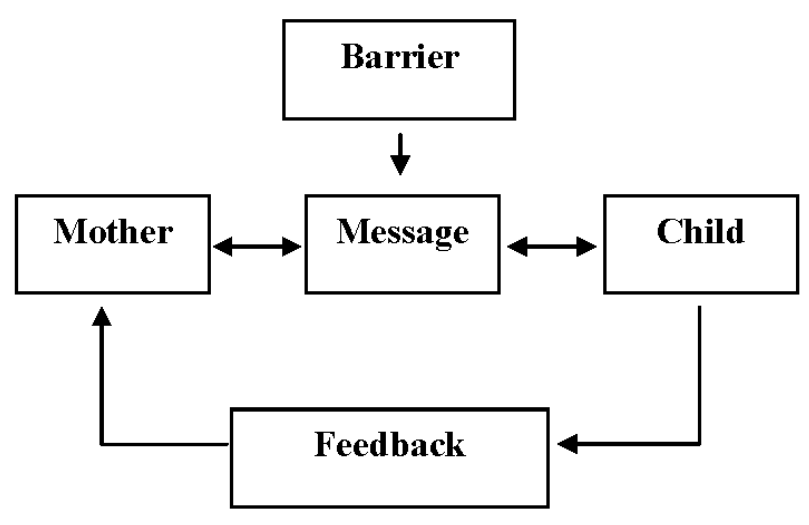

Figure 1. Interpersonal Communication Pattern between Female Breadwinners and Their Children 
As shown in Figure 1, the mother and the child can play roles as both the communicator and communicant interchangeably. Furthermore, a feedback or response is necessary in the communication process. The message being conveyed is usually communicated face-to-face (directly) in that the topics of the conversation between the mother and the children are related to their daily activities.

1. One-Way Communication Pattern

One-way communication happens when a mother tries to explain to her children such family's conditions as the fact that she earns more than their father does, her marriage will end in divorce, or their father is sick, or when a mother instills the values of discipline and independence in her children.

2. Two-Way Communication Pattern

Two-way communication between a mother and her children is closely related to the children's activities. The mother, when accompanying her child in studying, listens and responds to her child's story about his/her friendship at school. This type of communication happens not only when the mother is accompanying the children in studying, going out with them for shopping, or dining out, for instances, but also when the mother gives responses to the children's pique that is sometimes just caused by their uncontrolled emotion.

The above elaboration shows that a mother's roles as both a communicator and communicant in the communication process are very important, particularly when it comes to her commitment to making her family's condition better. Ballard-Reisch et al. (2006) point out that good communication is a means of measuring the happiness of a family (Bakar \& Aftanorhan, 2016).

\section{Barriers in Communication between Female Breadwinners and Their Children}

It is very common in communication for a barrier to exist, and this is no exception for a family with a female breadwinner. The followings are the barriers that most likely exist in the process of communication between female breadwinners and their children:

1. Barriers from the communicator

Mrs. Yopi said that tiredness was the main barrier for her to be able to deliver messages effectively to her children or husband. Further, she added that it was very difficult to manage her emotion when she felt tired (an interview with Mrs. Yopi Tri Kumalasari, September 2017). Another source, Mrs. Rika, mentioned the obstacles she had in being consistent, which would then hinder the inculcation of discipline and independence in her children. This inconsistency was because when she had to do everything on her own or when her children had a tantrum they did not want to do their routine activities on their own, and she tended to let it be and just helped them. (An interview with Mrs. Rika Dian Mayawati, September 2017).

2. Barriers in the coding/symbolizing

Mrs. Amalia revealed that the children's intense emotion or rebellion that sometimes came up when she tried to give them understanding made the messages being conveyed unclear. In addition, when her children said something while crying, she found it very difficult to understand what they wanted. (An interview with Mrs. Amalia Surya, September 2017).

3. Barriers from the media

Mrs. Prapti expressed her inability to operate a cellphone, causing her to have difficulties in keeping in touch with her only child who worked quite far away from home, or even just in asking when he would get home. (An interview with Mrs. Prapti, September 2017).

4. Barriers in the language

As it is their mother who instilled resoluteness and discipline in them, the children thought that their mother was mean to them. (An interview with Mrs. Amalia Surya, September 2017). 
5. Barriers from the communicant

Mrs. Amalia said that when she gave her second child advice, her first child often got near the second and teased her, causing her attention to be diverted. Further, Mrs. Amalia added that her first child's emotion was unstable due to her puberty period, leading to ignorance of what she said.

The data in this study reveal that barriers are most likely to hinder the process of communication between female breadwinners and their children. The main barrier is the limited time available for them to take care of their family. Another barrier is related to the children's psychological condition in which the lack or even absence of a father's figure leads to their unstable emotion.

\section{CONCLUSIONS}

Based on the above discussion, it can be concluded that the interpersonal communication between female breadwinners and their children runs well, as indicated by the presence of every factor that leads to effective communication. Those factors are 1) openness - it appears in the mother's active roles in making her children comfortable to tell her everything in the communication process; 2) empathy - the mother teaches her children how to be empathic through the inculcation of such values as independence and respect for others, especially for their parents; and 3) positive behaviors - the mother shows a firm commitment to improve the condition of her family.

In terms of the communication pattern, female breadwinners and their children have a direct (face-to-face) interpersonal communication pattern, either one-way or two-way. This pattern is indicated in their interchangeable roles as both the communicator (sender) and communicant (recipient) of the messages. The examples of one-way communication are when a mother explains the family's condition to her children (the facts that their father is sick, she has better salary than their father has, or she has decided to get a divorce) or when she tries to teach her children to be disciplined and independent. Meanwhile, a two-way communication happens when the mother, when accompanying her child in studying, listens and responds to her child's story about his/her friendship at school, when she takes her children out for shopping or dining out while sharing their thought about what they want, and when she responds to her children's pique that is sometimes caused by their uncontrolled emotion.

At last, the fact that female breadwinners do not have much time to spend with their family has caused them to be unable to fulfill their main responsibilities as a mother. Moreover, their children's psychological condition is also affected by the lack or even the absence of a father's figure, leading to a relatively unstable emotion. These barriers can certainly hinder the communication process between female breadwinners and their children.

\section{REFERENCES}

Aw, Suranto. (2011). Komunikasi Interpersonal. Yogyakarta: Graha Ilmu

Bakar, A. A., \& Afthanorhan, A. (2016). Confirmatory Factor Analysis on Family Communication Patterns Measurement. Procedia-Social and Behavioral Sciences, 219, 33-40.

Clark, A. (200o). The New Poor Law and the breadwinner wage: contrasting assumptions. Journal of Social History, 34(2), 261-281.

Cleverimania. (2013). Laporan Kasus: Kurangnya Pengawasan Orangtua terhadap Pergaulan Bebas Anak Remaja. Jakarta: Universitas Yarsi.

Creswell, J. W., \& Miller, D. L. (2000). Determining validity in qualitative inquiry. Theory into practice, 39(3), 
124-130.

Cunningham, M. (2008). Changing attitudes toward the male breadwinner, female homemaker family model: Influences of women's employment and education over the lifecourse. Social forces, $87(1)$, 299-323.

Denzin, Norman K. dan Yvonna S. Lincoln (eds.). (2009). Handbook of Qualitative Research. Terj. Dariyatno et al. Yogyakarta: Pustaka Pelajar.

Drago, R., Black, D., \& Wooden, M. (2005) said that Female breadwinner families: Their existence, persistence and sources. Journal of Sociology, 41(4), 343-362.

Ernawati, E. (2014). Menyibak Perempuan Kepala Keluarga. MUWAZAH, 5(2).

Hopson, D.P. and Hopson, D.S. (2002). Menuju Keluarga Kompak: 8 Prinsip Praktis Menjadi Orangtua yang Sukses (Translated by Muhammad Illyas). Bandung: Kaifa

Latshaw, B. A., \& Hale, S. I. (2016). 'The domestic handoff': stay-athome fathers' time-use in female breadwinner families. Journal of Family Studies, 22(2), 97-120.

Meisenbach, R. J. (2010). The female breadwinner: Phenomenological experience and gendered identity in work/family spaces. Sex Roles, 62(1-2), 2-19.

Noh, C. H. C., Yusooff, F., \& Hasim, M. S. (2013). Communication patterns of Malay families in Terengganu, Malaysia. Procedia-Social and Behavioral Sciences, 102, 635-642.

Nurdianti, S. R. (2014). Analisis Faktorfaktor Hambatan Komunikasi Dalam Sosialisasi Program Keluarga Berencana Pada Masyarakat Kebon Agung-Samarinda. Volume, 2, 145-159.

Pawito. (2007). Penelitian Komunikasi Kualitatif. Yogyakarta: LKiS.

Sudjana. (200o). Dasar-dasar Proses Belajar
Mengajar. Bandung: Sinar Baru Agensindo.

Sumardiningsih, Sri et al. (2001). Strategi Mempertahankan Kelangsungan HidupKeluarga yang Dikepalai Wanita pada saat Krisi Ekonomi di Daerah Istimewa Yogyakarta. Yogyakarta: PSW-UNY.

Syarifatisnaini. (2014). Efikasi Diri pada Remaja Korban Peceraian Orangtua. Surakarta: Psikologi - UMS.

Talibo, E. P., Boham, A., \& Rondonuwu, S. A. (2017). Pola Komunikasi Keluarga Yang Menikah Diusia Dini Di Desa Sonuo Kecamatan Bolaang Itang Barat Kabupaten Bolaang Mongondow Utara. JURNAL ACTA DIURNA, 6(2).

Widjaja. H.A.W. (200o). Ilmu Komunikasi Pengantar Studi. Jakarta: Rineka Cipta.

Wooden, M., \& Hahn, M. (2014). Female breadwinner families. Families, Incomes and Jobs, 9(57), 57-6o.

Nasib Miskin Jutaan Perempuan Kepala Keluarga di Indonesia: http://www. babylonish.com/blog/2015/o1/nasibmiskin-jutaan-perempuan-kepalakeluarga-di-indonesia

Pemberdayaan Perempuan Kepala KeluargaPEKKA: http://www.pekka.or.id/ index.php/id/tentang-kami/276pemberdayaan-perempuan-kepalakeluarga-pekka.html

Perilaku kriminalitas anak dan remaja http://www.kemenpora.go.id/ pdf / P E NYAJ I A N \% 2 o DATA \% 20 INFORMASI\%2OKEMENTERIAN\%20 P E M U D A \% 2 O D A N \% 20 OLAHRAGA\%2oTAHUN\%202009.pdf, diakses pada Rabu tanggal 24 Februari 2016, Pk. 10 : 26 WIB

Sry Ayu Rejeki: http://scholar. googleusercontent.com/scholar?q=cac he:4WranLTHvIoJ:scholar.google.com /+jurnal+komunikasi+keluarga\&hl=en \&as_sdt=0,5\&as_vis=1 